\title{
ON EDMUND SCHLINK (1903-1984)
}

\author{
Piet Naudé \\ The Unit for Professional Ethics \\ Nelson Mandela Metropolitan University
}

\begin{abstract}
This paper starts with a theologically interpreted life-story of Edmund Schlink. Thereafter his view of an ecumenical dogmatics is discussed, before the theme of church unity in the context of the ecumenical movement is outlined. The paper concludes with an application of Schlink's view to the South African context.
\end{abstract}

\section{Key Words: Edmund Schlink, Narrative Theology, Ecumenical Dogmatics, Church Unity}

It is a huge and almost impossible task to 'tell the story' of one of the greatest ecumenical theologians of the $20^{\text {th }}$ century. I will, nevertheless, attempt to give some insight into his life and work in three sections below. Although Edmund Schlink does not himself utilize an overt 'narrative' form of theology, it is possible to give a theological account of his lifestory and his work, and to draw some conclusion of that 'narrative' for our theological narrative in Southern Africa.

In section one a biographical overview of Schlink's life will be given to provide the context in which he made his theological contributions. ${ }^{1}$ In section two his specific view of an ecumenical dogmatics will be outlined. ${ }^{2}$ In section three a brief exposition of one recurring theme in his writings - the unity of the church - is given. The paper is concluded with a short statement on the significance of his work and life for South African theology in the $21^{\text {st }}$ century. The four sections therefore move from a theologically interpreted life-story via a synthesis of core ideas in Schlink's work (ecumenics and church unity), to a critical reflection on our (my?) own theological story in this country.

My own encounter with Schlink has started quite late in my theological research. Unlike most contributors to our colloquium who have spent a life of study on a particular theologian, I only 'discovered' Schlink whilst on a sabbatical at the University of Heidelberg in Germany in 1997-8. I saw his picture on the wall above the library and immersed myself in the many interesting works collected in the Ecumenical Institute where Schlink spent the longest part of his career. Ever since that time, he has been a constant partner in my own ecumenical journey. It is a great pleasure to introduce him to a wider English speaking audience.

\footnotetext{
For the first section I gratefully acknowledge the use of Eugene M Skibbe: A quiet Reformer. An introduction to Edmund Schlink's life and ecumenical theology (1999), although some of the interpretations are my own. See also the abbreviated CV of Schlink in Eber 1993:278-279.

2 Schlink's massive Ökumenische Dogmatik of more than 800 pages (referred to as $O ̈ D$ below) is my primary source for both sections two and three. Some of the material were published earlier some of these also in English. I will refer to the new edition of Schlink's work where his Dogmatik appears as Band 2 of Schriften zu Ökumene und Bekenntnis (2005). Unfortunately this major work, originally published in 1983, and receiving more than 30 reviews in academic journals around the world, has never been translated into English, depriving many theologians and church leaders of his influence. For a full list of Schlink's 246 publications, excluding unpublished sermons, see Eber 1993:274-289. For the sake of brevity, I have not cited the growing number of secondary studies on Schlink's work.
} 


\section{Section One: Biography and Context}

Edmund Schlink was born on 6 March 1903 in Darmstadt. He completed a broad, classical school education before studying mathematics, philosophy and physics at various universities, eventually settling in Marburg. His parental home was Christian oriented with his father from Catholic and his mother from Protestant (Hernnhut Pietist) background. By late 1925 - in the aftermath of the First World War - he experienced a deep 'Sinnkrise' and attempted to find meaning from the works of Dostoyevsky and Nietzsche. 'Why live at all?' was the basic existential question that took him to work on a farm in Silesia in an attempt to find direction in his life. In January 1926 - influenced by the witness of Christians from a mystical Lutheran background - he made a personal conversion to Christ and decided to study theology.

His parents insisted that he complete his science studies in Marburg. He did however change direction to psychiatry and in 1927 completed a doctorate in clinical psychology with an empirical analysis of religious experience: Persönlichkeitsänderunge in Bekehrung und Depressionen: Eine empirisch-religionspsychologische Untersuchung. Nebst kasuistischen Beiträgen zur Psychologie des Gotteserlebens als Anhang. ${ }^{3}$

He started his college-level theological education at Bethel Theological School near Bielefeld, but soon decided to go to Münster for a full university education, drawn there by the presence of professors Barth (dogmatics) and Stählin (practical theology). Barth had already published his Prolegoma zur Christlichen Dogmatik in the summer of 1927, and would commence his work on the $K D$ in 1931. Barth taught on ethics at Münster (19281929) and Bonn (1930-1931) at the same time that Schlink approached him to work on a doctorate in theology.

Barth's radical theological and Christological approach to ethics and anthropology (the human being under God's Word) seemed to contradict both the empirical method and subject matter of Schlink's work on religious experiences. Schlink in the mean time became active in the Lutheran church, entered the seminary in Friedberg, and was ordained as pastor in 1931. He nevertheless completed his theological doctorate under Barth in 1930 on the topic Emotionale Gotteserlebnisse: Ein empirisch-psychologischer Beitrag zum Problem der natürlichen Religion (Johann Ambrosius Barth: Leipzig 1931).

Barth's early influence on Schlink is evident from the fact that there is a clear emphasis on a theo- and Christocentric interpretation of anthropology as studied via an empirical analysis of religious experiences (see Schlink 1931:152-168). Schlink discusses the reality of purported 'God-experiences' in relation to the classical questions of natural religion and the tension between general and specific revelation. The only plausible 'explanation' for human experiences of God, asserts Schlink, is God's work of grace through Scripture and Christ. Knowledge of God is - as Luther argued, not attainable via experience or rational enquiry (1931:164), neither without God's self-revelation (1931:153). ${ }^{4}$ In his commendatio of the doctoral dissertation, Barth notes that Schlink's scientific analysis of 'nature' leads us to be confronted with 'grace' as there is no point of contact in nature for God's radical grace (Skibbe 1999:22).

This Christo-centricity is further evident in Schlink's Habilitationsschrift, published in 1936 as Der Mensch in der Verkündigung der Kirche: Eine dogmatische Untersuchung

\footnotetext{
Marburg dissertation, 1927; partially published in 1929, Archiv fur die gesamte Psychologie 70, 81-118.

Schlink writes that the question of truth in relation to "emotionale Heilserlebnisse ist theologisch als die Frage nach der Wirklichkeit einer Erkenntinis der göttlichen Gnade oder da Gotteserkenntnis ohne Gottes Offenbarung nicht möglich ist nach der Offenbarung der göttlilchen Gnade in den emotionalen Heilserlebnissen zu bestimmen" (1931:153, my emphasis).
} 
(München: Kaiser Verlag, 1936). The date of publication sets the dramatic context for this theological contribution where Schlink forcefully argues that not the human being, but only God working through Scripture, is the content and criterion of the church's proclamation. What was at stake was the simple, but absolutely fundamental question: How do we know God?

Two important 'audiences' should be assumed: Liberal theologians who saw anthropology - knowledge of the human person and his/her experience - as the starting point for knowledge of God. And secondly, the rising tide of German Christian theologians - many of them Lutheran - who claimed that historical events (such as the messianic significance of Hitler) constitute a new revelation of God. In typical Barthian sense, Schlink re-states that God is known through God's self-revelation in Christ and the gospel. And - drawing on his Lutheran roots - he asserts in his earlier Habilitation-lecture ${ }^{5}$ that God is hidden in history. One should therefore be careful to declare a historical situation a kairos moment as this can easily turn the voice of people into the voice of God, and shift normativity from God's Word to history. ${ }^{6}$ Revelation and truth only emanates from God's Word, proclaimed as law and gospel. ${ }^{7}$

Reflecting on the conclusion of Schlink's formal academic work, Eugene Skibbe asserts that "the earliest, most dominant drive in Schlink's life work was to create a Lutheran articulation of Barth's theology of the Word" (Skibbe 1999:22).

Schlink's biography would - in the next decade - be deeply affected by the rise to power of the National Socialists. He was appointed as teaching assistant at the small University of Giessen, but after only one semester his application for a full appointment in March 1935 was denied by the Nazi-oriented Ministry of Culture. He was invited back to Bethel Theological School where he taught and wrote what - up to today - became his best known book, Theologie der lutherischen Bekenntnisschriften (completed 1938, published in München by Kaiser Verlag, 1940). ${ }^{8}$

After the outbreak of the Second World War in 1939, the government increased its clampdown on dissident voices and Bethel School was ordered to close. Schlink was served with a gag order and he returned to pastoral work and bible study in Westphalia where in April 1940 he was again forbidden to speak in public. His application for exemption from military service was fortunately granted on the basis of his assumed indispensable service as wartime substitute pastor in the Westphalia region. When he was called or sought calls from churches, the Gestapo intervened on the basis that Schlink was not seen as loyal to the

5 "Die Frage der Erkenntbarkeit göttlichen Handelns in der Geschichte", published in Evangelische Theologie 1, 1934:257-277, and later included in the well-known collection Bekennende Kirche und Welt (Tübingen: Fruche Verlag, 1947), 26-42.

6 One can sense the passion with which Schlink writes that there is a huge difference between finding God's Word in history (revelation) and discerning God's Word for history (discipleship): "Für den Christen gibt es kein Gebot der Stunde, keine Forderung der Geschichte, keinen Anspruch eines irdischen Du. Für ihn gilt nicht: Volkes Stimme ist Gottes Stimme. Er kan in all dem keine Norm erblicken. Er hoert nicht mehr auf die Stimme der Situation, sondern hoert auf das Gotteswort für die konkrete Sitaution, für die Stunde, für die geschichtliche Lage, für die Stellung zum Du und zum Volk. Alles, alles muss Gott untertan warden" (Schlink 1947:42, emphases original). He earlier wrote that the basis of concrete historical knowledge is not history itself, but God's Word.

7 Revelation as law and gospel is a core theme in Schlink's later work, and a point of continued difference between Schlink and Barth. This fascinating debate is not pursued here. See the long exposition in his discussion of the Lutheran confessions (Schlink 1961:67-139), his interpretation of the second article of the Barmen declaration from the perspective of law and gospel (Schlink 1937:97-102) and ÖD, 234-250 (law) and 416-443 (gospel). See also Eber 1993:79-96.

8 The reason for this book's fame is to be explained from its wide use as textbook in Lutheran seminaries and its translation into English as Theology of the Lutheran Confessions in 1961 (Philadelphia: Muhlenberg). 
German Christian Church. He was - with other pastors - required to sign the oath of loyalty to Hitler at two occasions (1938 and 1941).

This was a matter of great tension and controversy. Schlink signed the oath as interpreted theologically by Karl Koch, who was present at the Barmen Synod and had signed the Barmen declaration, but who sought a compromise position between the views of the Bekennende Kirche and the Nazi government. Through this interpretation (and reflected in Schlink's own work) the ultimate loyalty to Christ was maintained, whilst being able to officially serve in the church during the war-time. ${ }^{9}$ After the invasion of France in June 1940, the Protestant and Catholic theological faculties in Strasbourg were closed. The Lutherans created their own seminary, the Thomasstift, and invited Schlink to become Director of Studies where he worked part time - travelling between Germany (Bielefeld) and France (Strasbourg) - over the next four years.

After the war, he was called to help reconstruct the theological faculty at Heidelberg University where he went as Professor of Dogmatics and Ecumenical Theology in 1946. Under the leadership of philosopher Karl Jaspers and other notable theologians such as Hans van Campenhausen (church history), Günther Bornkamm and Gerhard von Rad (OT), Schlink played a crucial role in re-establishing the university and the theological faculty in specific. His leadership was acknowledged with his election as rector for the 1953-1954 term. ${ }^{10}$

His major contributions during these Heidelberg years were his work in the ecumenical movement and in establishing systematic theology as a fundamentally ecumenical enterprise. Schlink's theological study in Münster already shaped his ecumenical mind: At a predominantly Catholic faculty, he was taught by Catholic, Reformed and Lutheran teachers and had to develop his own Lutheran convictions in open dialogue with others. The war - especially in the aftermath of massive air raids over Germany in 1943 - forced a pastoral situation upon clergy from different traditions to work in the tragic situation of mass burials of unidentified people. Pastor Schlink also served the Holy Communion to slave labourers from Ukrain and soldiers from different backgrounds. He later reflected and asked why such inter-confessional encounters cannot be maintained outside of crisis situations. "What in crisis situations in the church shines as the truth cannot in normal situations become untruth..." he remarked (see Skibbe 1999:48, and footnote 179). ${ }^{11}$

When he moved to Heidelberg after the war, Schlink played a major role in setting up various academic channels in service of a thoroughly ecumenical awareness:

- He was appointed to the first chair in Germany where Dogmatics and Ecumenical Studies were officially combined.

- Soon after his arrival in 1946, he set up what would become the famous Heidelberg Ecumenical Institute (predating the WCC Bossey Institute by a few months!). The primary aim was "to examine carefully the consonance and differences among Christian churches and the numerous efforts toward Christian unity in our time" (as quoted by Skibbe 1999:72, for original source, see Skibbe's footnote 245, page 146).

9 See my discussion of this choice in the closing section below.

10 Schlink's inaugural lecture is an absolute joy to read. Drawing on Luther's Heidelberg disputations from 1518 , he makes an argument that the university should promote wisdom rather than folly as reflected in the title, Weisheit und Torheit (Schlink 1953). This can only happen if science is approached from faith in Jesus Christ, as in this manner reason is brought under the control of love (Luther!) and the whole reality can truly be seen in all its richness and paradoxes under the Lordship of its Creator (see especially pages 21-22).

11 See how Schlink in a sermon in the Marienkirche in Dortmunt (1941) reflects on the un-natural deaths that war brings. He speaks of the Widernatürlichkeit of so many young people dying, but still links this to facing God's judgment (Schlink 1947:99). 
- He assisted in establishing the first German language journal for ecumenical thought, Ökumenische Rundschau, and published the opening article in the first edition on "The task and danger of the World Council of Churches". 12

- Schlink played a leading role over a period of 34 years (1945-1979) in the so-called JägerStählin Circle, ${ }^{13}$ a confidential dialogue group between Catholics and Lutherans that shaped his theological thinking on ecumenical relations with the Roman Catholic Church.

In addition to his theological studies, pastoral work, and academic activities in Heidelberg, Schlink gradually became a leading figure in the ecumenical movement, and played a crucial role over many years. There were hardly any major events in which he did not participate in some manner:

In the reconstruction of the Protestant churches after the war, Schlink was instrumental in the success of very delicate negotiations amongst different factions in the Lutheran Church and amongst Lutheran, Reformed and United churches that eventually formed the EKD in 1948. He was official delegate of the EKD to the founding of the WCC in Amsterdam in that same year and became a leading member of Faith and Order.

His stature in the WCC was confirmed when he - following his teacher, Karl Barth, who spoke in 1948 - was invited to be one of the opening speakers at the second meeting of the WCC in Evanston (1954). The theme was "Christ - the hope of the world". Schlink developed an eschatological view on ecumenism, reminding members that hope of God's new order includes a realization of the provisional nature of the church, its outward form, its church orders and its dogmatic formulations. "The church too will be transformed. In the new creation there will be no temple", he reminded, "for 'the Lord God Almighty and the Lamb are the temple'" (Rev xxi.22) (see Schlink, The coming Christ 1967:268). ${ }^{14}$

A crucial contribution was Schlink's attempt to develop an ecumenical hermeneutics. His article "Die Struktur der dogmatischen Aussage als ökumenisches Problem" (Kerygma und Dogma vol. 3, no. 4, 1957:251-306; The coming Christ 1967:16-84) later became a core part of his major work, Ökumenische Dogmatik (see chapter 3 of this book). This analysis of primary faith response forms serves - in my view - as methodological basis for his whole ecumenical theology (see section two below).

There were two further ecumenical endeavors that fundamentally shaped Schlink's thought and contributed to his mature ecumenical theology by 1983 :

The first was his direct and extensive involvement to convince the Russian Orthodox Church to apply for membership of the WCC in $1958 .^{15}$ The second was his official observer status at Vaticanum II where he noted the intense debates amongst Catholic theologians. He wrote 60 reports and more than 400 shorter analyses of these debates, and published Nach dem Konzil in 1966 (München: Siebenstern Taschenbuch Verlag; translated as After the Council 1968). It is no wonder that he was appointed inter alia

12 Included as a chapter in the English translation of collected essays The coming Christ and the coming church (1967).

13 Lorenz Jäger, the Catholic archbishop of Paderborn and Wilhelm Stählin, the Lutheran bishop in Oldenberg, set up the dialogue group in the early 1940's.

14 Schlink makes it clear that there are two intertwined acts of hope: The preaching of the gospel and "accepting responsibility for the just ordering of society" (1967:261-267, 262). God is not only Creator but also Sustainer. "God demands that we take responsibility for the preservation of all human life regardless of whether that life be a Christian or not, that we take responsibility for all men, regardless of their nationality, race or social status, and He also demands that we accept responsibility for their freedom" (1967:263, noninclusive language retained).

15 For an overview of the four-part role that Schlink played, read Skibbe 1999:83-89, and see Schlink's article "Zur neuesten ökumenischen Stellungnahme des Moskauer Patriarchates" in ÖR 7 (1958), 127-140. 
with WA Visser't Hooft, Nikos Nissiotis and Lukas Vischer to a joint task force to set up a closer link between the WCC and the RCC (see Skibbe 1999:90-98).

Schlink's intimate knowledge of the great faith traditions gradually led him to the conviction that the Lutheran church is well placed to play a significant ecumenical role.

Lutherans stand at a mid-point within ecumenical relationships - with the Anglican, Catholic and Orthodox churches to the right and Reformed, Congregationalist and Baptist churches as well as Quakers to the left. With its focus on the irreducible core of the gospel and the actual preaching of the living Word, the Lutheran tradition is able to see Christ in others and therefore strive for the unity of the church beyond the limits of Lutheranism. ${ }^{16}$ Although Schlink was undoubtedly a Lutheran theologian, his ecumenical spirit led him to a much broader vision of Christ's work beyond the boundaries of Lutheranism. A Copernican revolution in ecclesiological thinking occurs when Christ is thought of as the centre with different churches circling with one another around that center (After the Council 1968:248; $\ddot{O} D$, xxv, 695-6).

\section{Section Two: On an Ecumenical Dogmatics}

Schlink is well aware of various adjectives that are available to describe dogmatics: Christian, Catholic, Reformed, Orthodox or (like with Barth) Church Dogmatics. Many claim to call their work 'ecumenical' in the sense that dogmatics is a reflection on the faith of the one people of God. Schlink, however, finds this claim unsatisfactory: A mere claim to be ecumenical is not enough. What is needed is a specific scientific endeavour ('eine besondere wissenschaftliche Bemühung', $\ddot{O D}, 51)$ to construct an ecumenical theology with distinctive features.

The key to Schlink's ecumenical method lies in his well known exposition of primary faith responses ('elementäre Grundformen'), first published as 'Die Struktur der dogmatischen Aussage als ökumenisches Problem' (see reference above) and included in his $\ddot{O D}$ as chapter III.

Our response to the gospel, Schlink argues, is directed to God as well as to others and takes on the following primary forms: Prayer, doxology, witness, teaching and confession. After a careful analysis of these forms ( $\ddot{O} D, 33-39)$, he concludes that all the forms are present in condensed manner in confessions. To avoid morphological impoverishment through the tyranny of one faith response (like teaching) - resulting in a hardening of belief systems - all these primary forms need to be kept alive in faith communities and in the personal lives of believers $(\ddot{O} D, 40,47)$.

Because all of these responses are concerned with God, they are all theological expressions ('theologische Aussagen', ÖD, 40-41)) Schlink therefore does not define theological expressions as second order reflections upon God, but exactly these primary faith responses directed toward Godself.

'Dogmatic statements' are then to be understood as either statements of dogma or statements of dogmatics. The first is interpreted in the restricted sense where a church makes a statement of dogma (orthodox belief) that it requires for its life of faith. A confession ${ }^{17}$ in

16 See his paper prepared for the Third World Conference of Faith and Order in Lund (1952) on Die Weite der Kirche nach dem lutherischen Bekenntnis wherein he argues in typical Lutheran fashion that unity without confessional documents is possible as long as the pure gospel is preached and the sacraments celebrated accordingly. See also his discussion of the church in Theology of the Lutheran Confessions 1961:194-225.

17 See Schlink's discussion of the nature of confessions as the church's normative exposition of Scripture in his analysis of the Lutheran confessions (1961:xvi). He states that a study of the confessions is the actual prolegomena to dogmatics (see whole introductory section). 
the technical sense is such a statement of dogma. The second (dogmatics) is to be understood in a wider sense as including dogma, but extending reflection to other faith responses such as prayer, doxology and witness. History of theology ('Theologiegeschichte') is more than the history of dogma ('Dogmengeschichte'; $\ddot{O} D, 42$ ). In the light of these distinctions, an ecumenical dogmatics studies how the great deeds of God are responded to in an array of primary faith forms in the whole church of God.

For Schlink, the shift from one form to the other (e.g. doxology to confession) and the translation of one form into the other (prayer into witness), are both historically and theologically important. Historically, because this explains the structural shifts arising in the various epochs as churches responded to different needs at various stages of history. Theologically, because the primary focus of an ecumenical dogmatics is not to find exact wordagreements (consensus on dogmas, confessions) but to see consonance in content amongst various (seemingly unconnected) faith expressions, and to help churches in ecumenical dialogues to find a surprising unity amidst their diversity.

He then proceeds to explain an ecumenical dogmatics in negative terms (ÖD, 52-53):

- Ecumenical Dogmatics does not take the teaching of the own church as reference point and then seek to find partial representation of this true church in others from whom you are disunited in those instances where their teachings happen to agree with yours. In this way a true understanding of the other church - who also understands itself as the 'whole' church - is impossible. It furthermore fails to recognize the plurality of ways in which the richness of Christ finds expression in churches beyond the boundaries of your own.

- Ecumenical Dogmatics does not restrict itself to the ancient church's consensus as expressed in the first five centuries. This is a great temptation, as most churches that were formed up to and including the Reformation in fact acknowledge the decisions of the early Councils. But since the $17^{\text {th }}$ century many new faith communities in a variety of cultures were formed. For them the early consensus is not a part of their tradition. They find the nurturing Word of God and a strong missionary focus as adequate for their identity formation. Their presence and reality should be incorporated into a contemporary ecumenical dogmatics.

- Ecumenical Dogmatics cannot be restricted to a comparative study of contemporary differences amongst churches in order to find some middle ground of convergences. These comparisons are helpful as dogmatic pre-work, but are in themselves not dogmatic work yet. Such a 'comparative dogmatics' (ÖD, 57) would lead to an ecumenical minimalism and would not contribute to re-uniting the churches. No, ecumenical theology must show the courage to be 'maximalist' in converging churches around the apostolic faith.

- Ecumenical Dogmatics should also not occupy itself merely with a phenomenological analysis of pious religious experiences - even if they result from exciting ecumenical encounters. This approach would never appeal to dogmatic-founded churches; it denies the importance of common truth statements for church unity, and it opens the ecumenical process up for misuse by political and social currents of the day so that unity itself becomes an exponent of contemporary world -views. What then are - in positive terms - the core methodological components of an ecumenical dogmatics? (see $\ddot{O} D, 54-57)$.

- Ecumenical Dogmatics needs to acknowledge the rich plurality of Scriptural witnesses to the same saving acts of God. A specific act of God - including descriptions of Godself as Father, Son and Spirit - are not only expressed in a rich variety of metaphors 
and names, but are themselves witnesses to the rich variety of historical situations in which the biblical narratives arose.

- Ecumenical Dogmatics needs to acknowledge the rich plurality of dogmatic statements ('dogmatische Aussagen', ÖD, 54) within the boundaries of one church tradition and obviously amongst churches of different traditions. The specific historic situations in which these convictions were formed, are crucial for a proper understanding of their content. We do not need exactly the same formulations to express the same content, because the same truth can be expressed differently in the various primary forms ('Grundformen') of faith responses expounded above; and the same formulation can sometimes signify a different content to people reading them from different contexts.

For Schlink the core task of an ecumenical dogmatics is 'translation' work, i.e. to translate from and into various primary forms and from and into various historical contexts in order to establish surprising connections between faith responses that might

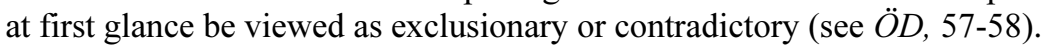

Once an ecumenical dogmatics reconstructs the plurality of contemporary dogmatic views as historical developments of the 'urchristlichen Bekenntnisaussagen' $(\ddot{O} D, 55)$, two conclusions are possible: First, one is able to see a unity amidst the plurality of seemingly contradictory viewpoints (they are all historical developments of the ancient Christian faith). Second, one is able to reconstruct these different views as manifold witnesses of the Spirit through the ages - just as there are many gifts in the church, appropriate for each situation.

- Ecumenical Dogmatics needs to focus on the actual role of dogma in the life of the churches. Churches tend to make implicit choices for certain dogmas or even certain parts of the canon. Churches who profess no formal confession, may in actual fact be upholding strong dogmatic views in the practical life of the faith communities (liturgy, pastoral and mission work). Conversely, so-called 'dogmatic' churches may in their faith communities not actually care so much about the orthodoxy they confess on paper.

- Ecumenical Dogmatics also focuses on confessions in the churches and understands these as conceptual concentrations ('begriffliche Konzentration', $\ddot{O} D$, 55) where the whole of the faith is expressed in a few words. Confessions are therefore always less than the fullness of faith or the multiformity of Scripture, and show legitimate historical differenttiation due to the development of faith in different traditions. For example: The Christologies of the East is shaped by the epiphany; whereas those of the West is shaped by the cross. They are thus both legitimately based on Scripture, despite their different emphases.

- Ecumenical Dogmatics does recognize the enormous potential to develop new dogmas as the gospel spreads over the earth into new cultures and spiritual climates. Ecumenical dogmatics cannot only restrict itself to already existing dogmas - specifically those that create disunity amongst churches - it must (in the light of the riches of Scripture!) be open for and willing to develop new confessions about Christ who not only came, but who is coming again $(O \ddot{D} D, 56)$.

\section{Section Three: On Church Unity}

It is to be expected that the unity of the church would play a significant role in Schlink's ecumenical theology. ${ }^{18}$ His ideas are represented in summarized form in three short sections:

18 The primary source of Schlink's ecclesiology is his exposition of the church in Theology of the Lutheran Confessions (1961:194-225). It is interesting to note that the church follows the discussion of gospel and sacraments and is presented in the context of the struggle between the kingdom of the devil and the kingdom of Christ. Jochen Eber's carefully writtten dissertation Einheit der Kirche als dogmatisches Problem bei Edmund Schlink (1993) is imperative secondary reading, especially 126-149. 
- What is the theological starting point for reflections on church unity?

- How do schisms amongst churches develop?

- How do we recognize the one church in a disunited Christianity and what are the crucial presuppositions in our striving for visible unity?

\section{Theological Starting Point}

It would be fair to represent Schlink's starting point on church unity as Trinitarian but with a Christological focus. All Christian communities are encapsulated by two acts of God: They were all founded on the basis of God's salvation in Jesus Christ and are all therefore grounded in grace. And they all are moving toward the judgment of God expected in the parousia of Christ. All churches live between cross/resurrection and second coming.

The thrust behind and the deepest ground of the ecumenical movement lie not in sociopolitical or pragmatic factors, but must be viewed as God's work through the Spirit: The ecumenical movement is a pneumatic movement $(\ddot{O D}, 683)$. Only God's Spirit can overcome ecclesial self-satisfaction, boasting in self-righteousness, laziness of theological thought and lack of creative love that resist unity in the church. ${ }^{19}$

Because the church is God's creation and because God keeps the church, a fundamental presupposition in seeking greater unity in a disunited Christianity is that the church is at all times the one, holy, catholic and apostolic church. No schism can diminish the always presupposed unity of the church. Yes, this unity may be made invisible or only partially visible by disuniting churches, but the unity can in principle not be negated because it is a gift of God based on the unity of Father, Son and Holy Spirit $(\ddot{O} D, 684)$.

The primary task of churches is not to re-establish unity, but to make two movements and in this specific sequence: Acknowledge the unity amidst a disunited Christianity; and then realize this unity in the re-establishment of church communion. If these two tasks are inverted, the very theological ground for seeking unity is destroyed and churches strive for unity no longer based on the indicative of grace but on the imperative of a self-defined ecumenical task $(O \ddot{D}, 685)$.

The Christological concentration of Schlink's presupposed theological grounds for unity emerges from two specific passages:

In his exposition of the marks of the church (ÖD, 585-589), Schlink clarifies that these marks are a description of the church as it is in Christ. The church's unity (for example) is not a characteristic of Christians, but derived from their being in Christ. The unity of the Church is Christ's unity that cannot be denied by our disunity.

In his discussion of how we could recognize the one church amidst a disunited Christianity, Schlink's often quoted passage about a Copernican paradigm shift further clarifies his Christological focus: Ecumenical relations are not promoted as long as the own church serves as reference point and criterion in the light of which all other churches are judged. "Wir haben die anderen christlichen Gemeinschaften nicht mehr so anzusehen, als ob sie sich um unsere Kirche als Mitte bewegen, sonder wir müssen erkennen, dass wir mit den anderen Gemeinschaften zusammen gleichsam wie Planeten um Christus als die Sonne kreisen und von ihm das Licht empfangen“ (ÖD, 696). This radical Christo-centric ecclesiological shift is a prerequisite for any real ecumenical progress, because it shifts the focus and criterion from any one church to Christ and the apostolic witness.

19 The original German is beautiful and impoverished by my poor translation: "Nur Gottes Geist vermag die Selbstzufriendenheit, die Rechthaberei, die Faulheit im Denken und den Mangel an Phantasie der Liebe zu beseitigen, die der Einheit entgegenstehen" (ÖD, 685). 
How do Schisms Develop Amongst Churches?

"Dass die Christenheit mit ihren Trennungen und Gegensätzen der Welt dasselbe Schauspiel bietet, wie diese im Neben- und Widereinander der Völker und Staaten, ist ein Skandal" $(\ddot{O D}, 683)$

With his many years of practical ecumenical dialogue and thorough knowledge of theological history, Schlink make some perceptive remarks:

He first demonstrates that disunity rarely if ever arises from outside the church. No, the drive for ecclesial self-preservation is the root of disunity. What happens is that the gifts for the preservation of the church the canon, dogma and church order are paradoxically the very factors in disuniting the church: The gospel of the canon, the living Word of God, is reduced to a mere prescribed reading of the Bible or a source of teachings, without the freedom of witness and prayer in the liturgy. The doxological ${ }^{20}$ and biblical roots of dogma as living response to God are stifled into strict orthodox statements about God. The variety of ministries emerging in New Testament times is fixated into neat hierarchical categories of laypeople versus church officials. The sad irony, says Schlink, is that all these things happen in the name of preserving unity, but they are often nothing more than self-preservation of a specific church tradition, cutting the church off from others and from God's call in the contemporary world to which it owes its service $(\ddot{O} D, 675)$.

Once self-preservation sets in, the scene is set for the rest of the disuniting factors to play their role:

If we accept that a schism is only to be considered when Christ is denied ('Abfall von Christus' or 'Verleungung Jesu Christi', $O D D$, 682), this legitimate reason is extended to present other factors in the same light by portraying them also as a fundamental denial of Christ. Schlink remarks that one has to carefully distinguish between historical reasons for a schism, and its aposteriori theological legitimization! ( $O \ddot{D}, 682)$.

If you see your church as the only true church, you increasingly use dogmatic means to reensure your difference with others, masking the many factors that unite you with them. You quickly enhance one point of difference into the whole gospel, blinding yourself for the work of Christ beyond the boundaries of your own church. If you then do seek re-unification, it is based on the assumption that the other must become and believe like you. The schismatic situation amongst Christians denies that Christ has conquered the world, and gives the world justification for its own schisms and enmities. This is a scandal $(\ddot{O D}, 683)$.

How do we Recognize the one Church in a Disunited Christianity and what are the Crucial Steps in our Striving for Visible Unity?

Based on his strong Christological starting point, Schlink first argues that we should recognize the one church exactly in the disunited Christianity. Even if Christ judges disunity in the church, $\mathrm{He}$ is able to work even in and through a disunited Christianity. $\mathrm{He}$ does not allow disunity in the church to disunite $\operatorname{Himself}(\ddot{O D}, 699)$.

Once we see Christ represented in a variety of ways in the whole church, it leads us to self-critique and confession of our part in disuniting the church. If we confess our sins by

20 There is no room to expound the importance of doxology in Schlink's construction of an ecumenical dogmatics. Doxology already appeared as a primary ground-form of faith responses (published in 1957); and doxology both introduces and closes his doctrine of God $(\ddot{O D}, 725 \mathrm{ff}$ and 790-792. Schlink does acknowledge Wainwright's Doxology that appeared about a year before the publication of $O ̈ D$ in 1983. For the link between doxology and reception of ecumenical documents, see Naudé 1998:252-254. 
turning to Christ, we are at the same time converting ourselves to one another. In stead of suspicion, and focusing on the past reasons for disunity, we then turn to other churches in hope - the hope to find in them a witness to Christ and a gift of the Spirit absent or marginalized in our midst $(\ddot{O} D, 695)$.

The way toward one another is via bi- or multilateral ecumenical dialogue based on both a hierarchy of truth ${ }^{21}$ and a hierarchy of church life. The Catholic Church and the WCC agree that belief in the Triune God and the acceptance of Christ as Saviour is the core of the Christian faith. In church life, there is - according to Schlink - a difference between specific church orders regulating officials' status and the preaching of the gospel of Jesus Christ. The inordinate energy spent on 'ministries' in ecumenical dialogues clearly inverts the order of importance that the Bible presents to us.

Schlink then lists seven practical ecumenical steps ${ }^{22}$ that are required to establish the visible unity of the church (see $\ddot{O} D, 700-708$ ):

1) There must be a striving for confessional consensus. As said earlier, this must not be restricted to traditional dogmatic differences, and should be addressed on the basis of the core truths of the apostolic faith - seeking to find and strengthen the many agreements already existing.

2) The reciprocal recognition of faith expressions even where these are not accepted by all in the exact wording of shared formulas. These faith expressions are recognized on the basis of the rich diversity of language used in the canon to describe the great deeds of God.

3) Reciprocal recognition of God's work in the practical life of other churches, specifically the way in which the salvation acts of God are expressed in a variety of liturgies. Once you accept that God is at work in the liturgy, the door is opened to recognize the ministries of another church as well.

4) The repeal of mutual condemnations ('Anathematismen', ÖD, 704) is a requirement for unity. Even though consensus might not be possible in each and every theological question, an anathema constitutes a fundamental contradiction to church unification.

5) The necessity of self-corrections by reinterpreting already accepted dogmas, and by being open to reformulate faith in the light of new situations. Fear of a disintegrating and plural identity is overcome by holding on to Christ to whom all faith formulations point.

6) The establishment of a shared faith community ('gottesdienstliche Gemeinschaft', ÖD, 706), including the invitation to holy communion by forgiving one another at the table of the Lord. There is no need to give up distinct liturgical identities as the pluriformity of prayer and worship is a testimony that God gives gifts appropriate for each time and context.

7) The shared growth toward unity, because unity is a continuous imperative based on a growth toward Christ and spurred on by the Holy Spirit. The Spirit creates in us the urgency for a greater visible unity in the church, and gives us the gifts of growing together in faith and love.

I conclude this section by referring (once again) to the eschatological horizon in which Schlink presents his ecumenical dogmatics. He admits that the church grew older than the

21 Schlink was deeply influenced by both Luther's idea of the "main articles" of faith and the Second Vatican Council's idea of a hierarchy of truths distinguishing between core and marginal dogmatic statements (see ÖD, 697).

22 This section may be related to Schlink's excellent paper (Oct 13, 1954) on "The task and danger of the World Council of Churches" (see Schlink 1967: 3-15). 
apostles and their followers had expected. But this does not mean that the church should loose its character as being called out of the world to live as the eschatological people of God. This does not mean any diminished sense of Christ's return to judge everything in heaven and on earth - including the church.

The real schism in the church will only be revealed in Christ's end-judgment. As is evident from Jesus' parables, the theological distinction between the visible and invisible church makes sense from the eschatological critique of the church by the coming Christ. And that schism - much more fundamental than the human schisms we have created - will cut across all churches: No part of Christ's body will be spared the schism of the true church from the false; the separation of the weed from the true harvest (ÖD, 685-687).

\section{Conclusion}

Edmund Schlink followed a different path than two of his better known contemporaries. Unlike Bonhoeffer who actively resisted National-Socialism and paid for that with his life, Schlink decided to work against National Socialism from within the church and under the rules of the state. ${ }^{23}$ Unlike Karl Barth who rejected the Hitler regime as outright evil, Schlink decided differently. He did not embrace main-stream Lutheran thinking that all governments - regardless of their stance - are creation orders instituted by God. But whilst professing his ultimate loyalty to Christ, he did hold onto the possibility that an evil state could be the mask behind which God acts, and that God could act - like in the case of Pharoah - against those very authorities to fulfill God's saving acts in history.

Looking back on his fundamental theological contributions to the Confessing Church ${ }^{24}$ and his rich ecumenical heritage, we might admit that there are different paths of faithfulness to God.

Schlink was recognized in his life-time with three honorary doctorates from the University of Mainz (1947), Edinburgh (1953) and the St Sergius Institute for Orthodox Theology in Paris (1962). He lived in Heidelberg, the basis of his major ecumenical and academic endeavours, where he died on 20 May 1984, a year after the first publication of his major book, Ökumenische Dogmatik. The re-edition of his writings in the first decade of the $21^{\text {st }}$ century is a most fitting reminder that the way beyond sectarianism and fundamentalism lies in a deep commitment and openness to others. This is superbly exhibited in the ecumenical spirit that fills the life and work of Edmund Schlink.

The question now remains: How does the 'story' of Schlink's life and work shape my and our narrative in South and Southern Africa? I would suggest three fundamental insights from Schlink that might assist us in our ecumenical and theological endeavours:

- First: Schlink's endeavour to establish a methodological base for an ecumenical dogmatics, and his actual construction of such a dogmatics - whether 'successful' or not - has significance for us. An ecumenical theology does not take as starting point some

23 In 1979 Schlink who knew and met Bonhoffer a few times said that "the kind of resistance was not the same, but we knew ourselves to be united in resistance" (Skibbe 1999, footnote 130).

24 A number of Schlink's contributions were published in Theologische Existenz Heute, and to see the intensity of the church struggle as waged by Schlink, it is imperative to read Bekennende Kirche und Welt which contains lectures and sermons from the period 1934-1945 (Schlink 1947). See for example his dramatic words from a lecture in Bonn in 1934 (published the next year in Th Existenz Heute, Heft 20). Speaking on how Israel rejected Christ, Schlink makes an almost direct application to the German situation: "Aber so wie damals űber der Gabe der allwirkende Geber vergessen wurde im Ruhm der eigenen Gerechtigkeit, so wird auch heute der dreieinige göttliche Geber vergessen über seinen Gaben, und die Geschichte wird anstelle Christi, und Blut und Rasse werden anstelle der Heiligen Geist gerühmt und geehrt."He calls this the paganism that has entered the German church and warns that the Bible is clear that God can take away the place of whole churches if they persist in idolatry (Schlink 1947:10). 
vague supra-confessional position or meta-Christological Archimedes point whence all other traditions are judged. An ecumenical theologian is rooted in a specific tradition, but she is able to relativize, critique and appreciate that tradition from the perspective of Christ, the apostolic faith, and the rich plurality of Christian beliefs and practices in other traditions. An ecumenical theologian actively addresses those theological questions pertaining to the visible unity of Christ's body and practical demands of the gospel in her specific context, but also on a catholic scale. Such a theologian is actively engaged in ecumenical bodies and practices, building networks of trust and love conducive to greater theological consensus.

It would be fair to say that - for historical reasons - Reformed theology ${ }^{25}$ dominates the public, academic scene in South Africa. It is therefore crucial that the spirit of these theologies is imbued with the ecumenical thrust of their origin in the Protestant Reformation; and that theologians from this tradition relativize themselves and their work in the light of Christ and other expressions of the faith in our context. Exactly because of their dominant position, sectarian Reformed theologies remain a temptation to avoid for the sake of Christ and the truth.

- Second: The TRC-report (1996) on faith communities in South Africa states that despite their professed faith to the contrary, these communities in fact were mirror images of the socio-economic divisions of an apartheid society. The church struggle tells an ambiguous story on two levels: Not only were churches divided amongst themselves about resistance to apartheid, but many churches who actively resisted and protested against the system of racial division, were themselves (and are in some cases still today) racially divided. Much has happened after 1994 in the political, social, sport and economic spheres to create visible signs of a shared citizenship based on the values and prescriptions of the South African constitution. And in the churches, much has happened to bring about greater visible unity amongst for example Apostolic Faith, Lutheran and Dutch Reformed churches. But much still remains to be done. ${ }^{26}$

There is - as Schlink argued - absolutely no theological reason why visible church communion amongst the traditional faith communities could not be realized. (Have we silently accepted these traditional schisms as "normal'?) With the dramatic growth of churches under the broad banner of Pentecostalism in South and Southern Africa, the issue of ecumenicity becomes more complex and at the same time more urgent. As Schlink reminds us, the eschatological critique of the church and her identity as 'tentpilgrims' should destroy all self-satisfaction or even self-righteousness in our midst. The scandal of disunity and the lack of enthusiasm for (re)-unification sometimes stand in sharp contrast to secular attempts in realizing a united South Africa. The question is whether a commitment to human rights and democratic political ideals are more powerful than the cross and resurrection of Jesus Christ whose physical body was broken for the sake of unity in his ecclesial body? A Christological concentration - the knowledge that we are one in Christ and should therefore become one, and that all churches circle around Christ as the centre - remains the only antidote to a laid-back attitude concerning the visible unity of the church.

25 There are obviously many different forms and emphases of "Reformed" theologies in South Africa, as Dirkie Smit rightly points out (see Smit 1992). See also De Gruchy's well known re-interpretation of this multifaceted tradition in the South African context (De Gruchy 1991).

26 From my own limited position in the DRC-family, I understand the step-like processes toward re-unification, but fear that our vision is too restricted to focus on this family alone. There are many churches in Africa to the north of us who belong in one church. And there are many other (Reformed) churches with whom some form of greater visible union is possible and important. 
- Third. There is little doubt that an ecumenical awareness and ecumenical practices were the most powerful bases of the struggle against apartheid. How can we forget the role of the WCC, the LWF, the WARC, and locally the Catholic Bishop's Conferences, the SACC and the DRMC to provide fundamental critique of apartheid theology in order to erode the moral basis of a race-based political system? The question is: Where is that same ecumenical commitment and enthusiasm for the new struggles against HIV/AIDS, neo-liberal capitalism, ecological destruction, disregard for human rights in Africa and elsewhere; and abject poverty amidst a growing economy and surplus state funds? The 'single enemy syndrome' and the obvious moral rightness of the struggle against apartheid played an 'energizing' role for the ecumenical efforts up to 1994.

We need an awakening of the Spirit to unite once again on issues that might not be politically correct, that might not reach the front pages of newspapers or the attention of TV crews, and that might challenge the policies of our democratic political leadership. The gospel of righteousness, with its imperatives superseding the significant normative guidelines of human rights, ${ }^{27}$ has not suddenly changed in 1994.

\section{BIBLIOGRAPHY}

De Gruchy, John 1991. Liberating Reformed theology. A South African contribution to an ecumenical debate. Grand Rapids: Eerdmans.

Eber, Jochen 1993. Einheit der Kirche als dogmatisches Problem bei Edmund Schlink. Göttingen: Vandenhoeck \& Ruprecht.

Naudé, Piet J 1998. Regaining our ritual coherence: The question of textuality and worship in ecumenical reception. Journal of Ecumenical Studies 35/2:235-256.

Naudé, Piet J 2007. Between humility and boldness: Explicating human rights from a Christian perspective. NGTT 48: 139-148.

Schlink, Edmund 1931. Emotionale Gotteserlebnisse: Ein empirisch-psychologischer Beitrag zum Problem der natürlichen Religion. Leipzig: Johann Ambrosius Barth.

Schlink, Edmund 1934. "Die Frage der Erkenntbarkeit gőttlichen Handelns in der Geschichte", Evangelische Theologie 1, 1934:257-277.

Schlink, Edmund 1936. Der Mensch in der Verkündigung der Kirche: Eine dogmatische Untersuchung. München: Kaiser Verlag.

Schlink, Edmund 1937. Das Lutherische Bekenntnis und die zweite These der Barmer theologischen Erklärung. Theologische Existenz Heute, Heft 53: 97-102.

Schlink, Edmund 1940. Theologie der lutherischen Bekenntnisschriften. Einführung in die evangelische Theologie. Bd.8. München: Kaiser.

Schlink, Edmund 1947. Bekennende Kirche und Welt: Vorträge und Predigten aus den Jahren 1934 bis 1945. Tübingen: FurcheVerlag.

Schlink, Edmund 1953. Die Weltkirchenkonferenz in Lund. ZW 24: 443-448.

Schlink, Edmund 1953. Weisheit und Torheit (Rektoratsrede). Kirche und Dogma 1: 1-22.

27 For a discussion of the relation between human rights and Christian theology, see Naude (2007), who argues that human rights need to be affirmed and sustained by Christians, as long as their limitations vis a vis the gospel are also kept in mind. To freely give your life (goods, gifts, time) for others a basic call in the gospel is obviously far more radical than a striving for autonomy, human dignity and self-affirmation based on the right to equality. 
Schlink, Edmund 1957. "Die Struktur der dogmatischen Aussage als őkumenisches Problem," Kerygma und Dogma 3/4 : 251-306.

Schlink, Edmund 1958. "Zur neuesten ökumenischen Stellungnahme des Moskauer Patriarchates" ÖR 7: 127-140.

Schlink, Edmund 1961. Theology of the Lutheran Confessions. Philadelphia: Muhlenberg.

Schlink, Edmund 1961. Der kommende Christus und die kirchlichen Traditionen.

Göttingen: Vandenhoeck \& Ruprecht.

Schlink, Edmund 1966. Nach dem Konzil. München: Siebenstern - Taschenbuchreihe 75.

Schlink, Edmund 1967. The coming Christ and the coming church. Edinburgh: Oliver \& Boyd (ET of Schlink 1961).

Schlink, Edmund 1967. The task and danger of the World Council of Churches, in The coming Christ and the coming church: 3-15.

Schlink, Edmund 2005. Schriften zu Ökumene und Bekenntnis. Band 2. Ökumenische Dogmatik. Göttingen: Vandenhoeck \& Ruprecht.

Skibbe, Eugene M 1999. A quiet Reformer: An introduction to Edmund Schlink's life and ecumenical theology. Minneapolis: Kirk House.

Smit, Dirk 1992. Reformed theology in South Africa: A story of many stories. Acta Theologica 12/1:88-110.

Wainwright, Geoffrey 1983. Doxology: The praise of God in worship, doctrine, and lifeA systematic theology. London: Epworth Press. 